\title{
Direct-acting Antiviral Therapy for Mixed Genotype Chronic Hepatitis C Infection
}

\author{
Miks Genotip ile Enfekte Kronik Hepatit C Hastalarında Direkt Etkili Antiviral Tedavi
}

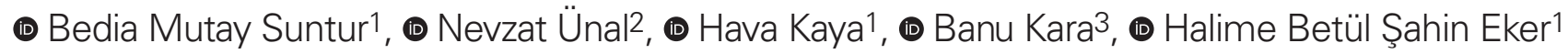

${ }^{1}$ Adana City Training and Research Hospital, Clinic of Infectious Diseases Adana, Turkey

${ }^{2}$ Adana City Training and Research Hospital, Clinic of Medical Microbiology, Adana, Turkey

${ }^{3}$ Adana City Training and Research Hospital, Clinic of Gastroenterology, Adana, Turkey

\begin{abstract}
Objectives: Literature data concerning the outcomes of direct acting antiviral (DAA) therapy in mixed genotype hepatitis $\mathrm{C}$ virus $(\mathrm{HCV})$ infections are very limited, and the incidence of mixed HCV infection in Turkey is unknown. The aim of this study was to investigate the prevalence of mixed genotype chronic HCV infection, risk factors related to mode of transmission and outcomes of DAA therapy in these patients.

Materials and Methods: Patients with two different HCV genotypes identified in the same blood sample during a 20-month period were analyzed retrospectively in terms of treatment received, adherence and response to treatment and risk factors related to mode of transmission.

Results: During the study period, mix genotypes were detected in $21(4.2 \%)$ out of 495 patients with chronic HCV infection. Fifteen patients $(71 \%)$ had a history of intravenous drug use. Eleven patients who received DAA treatment was HCV-RNA negative at the end of treatment.

Conclusion: According to our findings, infection with different HCV genotypes is possible in patients with repeated HCV exposure, such as intravenous drug users, but mixed HCV infection can be successfully treated with DAA therapy. In addition, our study may be noteworthy for also including mixed genotypes in the HCV epidemiological shift in our region.

Keywords: hepatitis C virus, HCV genotypes, mixed genotype HCV, direct-acting antivirals, intravenous drug use
\end{abstract}

\section{ÖZ}

Amaç: Miks genotip hepatit $\mathrm{C}$ virus (HCV) enfeksiyonlarının direkt etkili antiviral (DEA) ilaçlar ile tedavi sonuçlarına ilişkin çok az literatür verisi bulunmaktadır. Türkiye'de miks HCV enfeksiyonu görülme sıklığı bilinmemektedir. Bu çalışmada, miks genotip ile enfekte kronik hepatit $\mathrm{C}$ hasta prevalansının, bu hastalardaki bulaş yoluna ilişkin risk faktörlerinin ve DEA ilaçlar ile tedavi sonuçlarının incelenmesi amaçladı.

Gereç ve Yöntemler: Yirmi aylık çalışma periyodunda, aynı kan örneğinde iki farklı HCV genotipi saptanan hastalar, aldıkları tedavi protokolleri, tedaviye uyumları ve tedaviye yanıtları, bulaş yoluna ilişkin risk faktörleri açılarından retrospektif olarak incelendi.

Bulgular: Çalışma periyodu içinde genotip tayini yapılan 495 hastadan $21^{\prime} i(\% 4,2)$ iki farklı HCV genotipi ile enfekteydi. Bu hastaların 15'inde (\%71) damar içi madde kullanımı öyküsü vardı. DEA tedavi alan 11 hastada tedavi sonu HCV-RNA negatif bulundu. Sonuç: Bulgularımıza göre, damar içi madde kullanımı gibi HCV'ye tekrarlayan maruziyet durumlarında iki farklı HCV genotipi ile enfeksiyon olasıdır, miks HCV enfeksiyonu DEA ile başarılı bir şekilde tedavi edilebilir. Ayrıca çalışmamız, bölgemizdeki HCV epidemiyolojisindeki değişime miks genotiplerin de dahil edilmesi açısından dikkat çekici olabilir.

Anahtar Kelimeler: Hepatitis C virus, HCV genotip, miks genotip, direkt etkili antiviraller, damar içi madde kullanımı

Mutay Suntur B, Ünal N, Kaya H, Kara B, Şahin Eker HB. Direct-acting Antiviral Therapy for Mixed Genotype Chronic Hepatitis C Infection. Viral Hepat J. 2019;25:55-58. 


\section{Introduction}

Chronic hepatitis $\mathrm{C}$ virus (HCV) infection is a major cause of chronic liver disease. An estimated 71 million people are infected with HCV worldwide (1). In Turkey, the seroprevalence of HCV infection is reported to be 1\% (2). Seven genotypes and 67 subgenotypes of HCV have been described to date (3). The distributions of HCV genotypes and subgenotypes vary according to geographical location and mode of transmission. Genotypes 1, 2, and 3 are common globally, while genotypes 4, 5, and 6 are seen in certain geographical locations (4). Genotype $1 \mathrm{~b}$ is the most common, both globally and in Turkey $(4,5)$.

Because sufficient protective immunity does not develop following primary infection, reinfection is possible upon repeated exposure to HCV after the infection is eliminated either spontaneously or with treatment. Similarly, an individual may be infected with more than one genotype as a result of repeated exposure to HCV. Mixed HCV infection is used to describe patients infected with two or more different HCV genotypes simultaneously (6). Risk groups for repeated exposure to HCV and mixed HCV infection include intravenous drug users (IVDUs), hemodialysis patients, and patients needing frequent transfusion of blood and blood products, such as those with hemophilia $(6,7)$.

With the direct-acting antiviral (DAA) drugs currently used in the treatment of chronic HCV infection, genotyping remains critical for selecting an appropriate treatment protocol and duration, as it was for earlier interferon-based therapies.
Data concerning the outcomes of DAA therapy in mixed HCV infections are very limited $(8,9)$. In this study, we investigated the prevalence of mixed genotype chronic $\mathrm{HCV}$ infection, risk factors related to mode of transmission, and outcomes of DAA therapy in these patients.

\section{Materials and Methods}

Over a 20-month period from June 2016 and February 2018, HCV genotype analysis was performed for 495 patients diagnosed with chronic hepatitis $C$ infection. Genotyping was done using the HCV Genotype Plus Real-TM kit (Sacace Biotechnologies Caserta, Italy) in the first 14 months and Abbott RealTime HCV genotip 2 kit (USA) in the last 6 months. Patients with two different HCV genotypes identified in the same blood sample were analyzed retrospectively in terms of treatment received, adherence and response to treatment, and risk factors related to mode of transmission. The study was approved by the Ethics Committee of Adana City Training and Research Hospital (approval number: 276, date: 08.29.2018).

\section{Statistical Analysis}

Statistical analyses were done using SPSS version 20.0 (SPSS Inc., Chicago, IL, USA). Descriptive statistical methods were used. Findings were expressed in percent, mean, and standard deviation as appropriate.

\begin{tabular}{|c|c|c|c|c|c|c|c|c|}
\hline Patient No & Age (Year) & Gender (M/F) & Genotype & HCV-RNA (IU/mL) & Fibrosis & Treatment & SVR $^{\mu}$ & IVDU* \\
\hline 1 & 79 & $\mathrm{~F}$ & $1 b+3$ & 79448 & 6 & $S / L 24 w$ & Negative & No \\
\hline 3 & 39 & M & $1 b+4$ & 2118231 & 2 & PROD-R 12w & Negative & No \\
\hline 4 & 24 & $M$ & $1 b+4$ & 460617 & 2 & PROD-R 12w & Negative & Yes \\
\hline 7 & 46 & M & $1 b+4$ & 14008882 & NA & NA & NA & No \\
\hline 8 & 25 & M & $1 b+4$ & 11114825 & 1 & NA & NA & Yes \\
\hline 9 & 22 & M & $1 b+4$ & 10896696 & 2 & NA & NA & No \\
\hline 10 & 31 & M & $1 a+3$ & 18662 & NA & NA & NA & Yes \\
\hline 14 & 32 & $\mathrm{~F}$ & $2+4$ & 93060 & 1 & S/L-R 12w & Negative & No \\
\hline 15 & 25 & $\mathrm{~F}$ & $3+4$ & 1011756 & 2 & NA & NA & Yes \\
\hline 16 & 29 & M & $1 b+3$ & 568124 & NA & NA & NA & Yes \\
\hline 17 & 27 & M & $2+3$ & 152231 & 3 & S-R 24w & Negative & Yes \\
\hline 18 & 26 & $\mathrm{M}$ & $2+3$ & 816 & 1 & NA & NA & Yes \\
\hline 19 & 28 & M & $2+3$ & 8119 & 1 & S-R 24w & Negative & Yes \\
\hline 20 & 28 & $\mathrm{M}$ & $1 b+4$ & 536827 & 2 & PROD-R 12w & Negative & Yes \\
\hline 21 & 31 & $M$ & $2+3$ & 3928824 & 2 & NA & NA & Yes \\
\hline
\end{tabular}




\section{Results}

Of the 495 patients that underwent genotyping during the study period, 21 (4.2\%) were infected with two different HCV genotypes. Eighteen (85\%) of those patients were males and the mean was $31.7 \pm 12.71$ (22-79) years. Transmission-related risk factors included IVDU in 15 (71\%) patients, posttraumatic multiple blood transfusions in 1 patient, and 2 of the patients were immigrants from Syria. Genotype 1b-4 (7 patients) and genotype 2-3 (6 patients) were the most frequent genotype combinations. Of the 21 patients with mixed HCV infection, 10 were not under follow-up and had not received treatment. Eleven patients who received DAAs completed treatment and tested negative for HCVRNA at post-treatment. Following treatment, 6 patients attended follow-up for varying periods (2-9 month). The HCV-RNA values of these patients remained negative during follow-up. Treatment protocols and outcomes of the patients are given in Table 1.

\section{Discussion}

The prevalence of mixed HCV infection varies with the patient population and the sensitivity of the method used for genotyping. In studies conducted in the general patient population in various countries, the prevalence of mixed $\mathrm{HCV}$ infection ranges between 2.2\%-7.3\% (9-12). In a study in England on groups at risk of repeated exposure to $\mathrm{HCV}, 9 \%$ of hemophilia patients were found to have mixed HCV infection, while the ratio increased to $19 \%$ among IVDUs (7). No data are available in Turkey regarding the prevalence of mixed $\mathrm{HCV}$ infection in the general population or in specific patient groups. In our study, the ratio of mixed HCV infection was $4.2 \%$. The fact that $71 \%$ of these patients had a history of IVDU may be a notable finding regarding the mode of transmission of mixed $\mathrm{HCV}$ infection in our region. It has been reported that using more sensitive genotyping methods can reveal higher rates (14-39\%) of mixed HCV infection in IVDUs (6). Mixed HCV infection may develop as a result of coinfection (infection with two different genotypes of $\mathrm{HCV}$ at the same time) or superinfection (a different genotype of $\mathrm{HCV}$ is added to an existing HCV infection) $(13,14)$.

Although sequence analysis is considered the gold standard in HCV genotyping, it is difficult and costly. Therefore, routine diagnostic laboratories utilize the line probe assay method, developed as a commercial kit based on reverse hybridization, or real-time PCR-based methods using genotype-specific primers. Some of these target only the 5'UTR region, while others target the $5^{\prime}$ UTR region as well as core or NS5B regions. Targeting multiple regions is reported to increase the sensitivity of accurate genotype and subgenotype identification (15). In our study, we used commercial sets based on one-step, real-time PCR with primers targeting $5^{\prime} U T R$ in the first 14 months and $5^{\prime}$ UTR and NS5B in the last 6 months.

In many studies on mixed HCV infection, standard commercial genotyping tests are accompanied by sequence analysis. It was emphasized in these studies that standard genotyping methods may effectively identify the dominant genotype, but may not be able to detect minor genotypes that account for less than $20 \%$ of the viral population, thus underestimating the actual prevalence of mixed HCV infection. Furthermore, after treatment has successfully eliminated the dominant genotype, it may be superseded by the minor genotype, which may be misinterpreted as relapse/reinfection. Therefore, it is strongly recommended to repeat genotyping in cases of failed treatment $(6,10,12)$.

There are very limited data on the outcomes of DAA therapy in mixed HCV infection $(8,9)$. In a study conducted in Spain, failed DAA therapy was reported in 2 of 6 patients with mixed HCV genotypes (9). In our study, post-treatment HCV-RNA was negative in 11 patients treated with DAA for mixed HCV infection. Of these patients, those still under follow-up were found to have sustained HCV-RNA negativity. Having only recently been licensed, pangenotypic DAA drugs were not covered by medical insurance in Turkey in the time period that we did our study. Treatment protocols for our patients are determined according to the European Association for the Study of the Liver 2016 guidelines and the conditions of reimbursement in our country (16).

Epidemiological studies on HCV infection have demonstrated changes in both patient demographic profile and genotypic distribution in the last 20 years, with genotype 1 gradually being replaced by genotype 3 with the increased use of safe blood and blood products. This shift has been mainly attributed to IVDU becoming a significant mode of transmission $(4,17)$. As in the rest of the world, previous studies have reported similar changes in HCV genotype distribution in Turkey, and it was also suggested that IVDU may be a factor in this shift $(18,19)$.

On the other hand, in 2016 the World Health Organization called for the eradication of HCV (20). HCV eradication seems to be an attainable goal, given that DAA drugs are already in use. However, IVDUs, who constitute a reservoir for $\mathrm{HCV}$, are considered one of the main barriers facing eradication programs $(17,21)$. It has been shown in modeling studies that DAA drugs in this patient group can go beyond treating the infected person and break the chain of transmission at the community level, thus minimizing new cases; this phenomenon has been termed "treatment as prevention".

Although DAA drugs are available and covered by insurance in Turkey, all of the patients in our study with mixed HVC infection who quit follow-up and remained untreated had a history of IVDU, which indicates their unwillingness to receive treatment. These untreated patients can potentially act as a mixed genotype reservoir in the chain of infection. To the best of our knowledge, this is the first study on mixed HCV infection in Turkey, and we believe it contributes to the limited literature data concerning the outcomes of DAA therapy in mixed HCV infection.

\section{Study Limitations}

Limitations of this study are that not all patients with mixed $\mathrm{HCV}$ infection received treatment and long-term follow-up results were not available for all of the treated patients. Also we conducted a retrospective study of the records.

\section{Conclusion}

Our findings indicate that although mixed $\mathrm{HCV}$ infection can be successfully treated with DAAs, making these drugs available is not enough to prevent HVC infection. Public health policies should be developed to motivate at-risk groups to receive treatment. 


\section{Ethics}

Ethics Committee Approval: The study was approved by the Ethics Committee of Adana City Training and Research Hospital (approval number: 276, date: 08.29.2018).

Informed Consent: Retrospective study.

Peer-review: External and internal peer-reviewed.

\section{Authorship Contributions}

Surgical and Medical Practices: B.M.S., H.K., B.K., Concept: B.M.S., Design: B.M.S., Data Collection or Processing: N.Ü., H.K., H.B.S.E., Analysis or Interpretation: B.M.S., H.K., Literature Search: B.M.S., Writing: B.M.S., B.K.

Conflict of Interest: The authors declare no conflict of interest.

Financial Disclosure: The authors declare that this study has not received any financial support.

\section{References}

1. World Health Organization. Global hepatitis report 2017. World Health Organization, 2017. Available from: http://www.who.int/ hepatitis/publications/global-hepatitis-report2017/en/

2. Tozun N, Ozdogan O, Cakaloglu Y, Idilman R, Karasu Z, Akarca U, Kaymakoglu S, Ergonul O. Seroprevalence of hepatitis B and C virus infections and risk factors in Turkey: a fieldwork TURHEP study. Clin Microbiol Infect. 2015;21:1020-1026.

3. Smith DB, Bukh J, Kuiken C, Muerhoff AS, Rice CM, Stapleton JT, Simmonds P. Expanded classification of hepatitis $C$ virus into 7 genotypes and 67 subtypes: updated criteria and genotype assignment web resource. Hepatology 2014;59:318-327.

4. Petruzziello A, Marigliano S, Loquercio G, Cozzolino A, Cacciapuot C. Global epidemiology of hepatitis C virus infection: An up-date of the distribution and circulation of hepatitis $C$ virus genotypes. World J Gastroenterol. 2016;22:7824-7840.

5. Yamazhan T, Taşova $Y$, Candevir AU, Karsen H, Esen Ş, Çuvalcı NÖ, Sarıgül $F$, Önlen $Y$, Yörük $G$, Sarı ND, Yıldız $\mid E$, Inan $D$, Zerdali E, Kayaaslan B, Barut Ş, Karaosmanoğlu HK, Köksal I, Kaya S, Ince N, Gündüz Alper, Namıduru M, Batırel A, Günal Ö, Coşkuner SA, Bodur H, Tosun S, Gül HC, Sırmatel F, Türker K, Duygu F, Sünnetçioğlu M, Erben N, Karabay O, Şener A, Şenateş E, Çelebi G, Tartar AS, Baykam N, Tabak F. Türkiye'de Kronik HCV Enfeksiyonunun Profili: Çok Merkezli HEP-C Çalışmasının Sonuçları. Mediterr J Infect Microb Antimicrob. 2018. EKMUD Kongresi. 8-13 Mayıs 2018. Antalya, SS. 195: Supplement 1:1308.

6. Cunningham EB, Applegate TL, Lloyd AR, Dore GJ, Grebely J. Mixed HCV infection and reinfection in people who inject drugsimpact on therapy. Nat Rev Gastroenterol Hepatol. 2015;12:218230.

7. Buckton AJ, Ngui SL, Arnold C, Boast K, Kovacs J, Klapper PE, Patel B, Ibrahim I, Rangarajan S, Ramsay ME, Teo CG. Multitypic hepatitis $\mathrm{C}$ virus infection identified by real-time nucleotide sequencing of minority genotypes. J Clin Microbiol. 2006;44:2779-2784.
8. Uribe-Noguez LA, Ocaña-Mondragón A, Mata-Marín JA, CázaresCortázar A, Ribas-Aparicio RM, Gómez-Torres ME, GaytánMartínez J, Martínez-Rodríguez ML. Case report: Identification of recombinant HCV genotype $1 \mathrm{~b}-2 \mathrm{~b}$ by viral sequencing in two patients with treatment failure, who responded to re-treatment with sofosbuvir and daclatasvir. J Infect Chemother. 2018;24:928931.

9. Del Campo JA, Parra-Sánchez M, Figueruela B, García-Rey $S$, Quer J, Gregori J, Bernal S, Grande L, Palomares JC, RomeroGómez M. Hepatitis C virus deep sequencing for sub-genotype identification in mixed infections: A real-life experience. Int $\mathrm{J}$ Infect Dis. 2018;67:114-117.

10. Schröter M, Feucht HH, Zöllner B, Schäfer P, Laufs R. Multiple infections with different HCV genotypes: prevalence and clinical impact. J Clin Virol. 2003;27:200-204.

11. Gowin E, Bereszynska I, Adamek A, Kowala-Piaskowska A, MozerLisewska I, Wysocki J, Michalak M, Januszkiewicz-Lewandowska D. The prevalence of mixed genotype infections in Polish patients with hepatitis C. Int J Infect Dis. 2016;43:13-16.

12. McNaughton AL, Sreenu VB, Wilkie G, Gunson R, Templeton $K$, Leitch ECM. Prevalence of mixed genotype hepatitis $C$ virus infections in the UK as determined by genotype-specific PCR and deep sequencing. J Viral Hepat. 2018;25:524-534.

13. Blackard JT. HCV superinfection and reinfection. Antivir Ther. 2012;17:1443-1448.

14. Walker MR, Li H, Teutsch S, Betz-Stablein B, Luciani F, Lloyd AR, Bull RA. Incident Hepatitis C Virus genotype distribution and multiple infection in Australian prisons. J Clin Microbiol. 2016;54:1855-1861.

15. Kumar A, Rajput MK, Paliwal D, Yadav A, Chhabra R, Singh S. Genotyping \& diagnostic methods for hepatitis $C$ virus: A need of low-resource countries. Indian J Med Res. 2018;147:445-455.

16. European Association for The Study of The Liver. EASL recommendations on treatment of hepatitis C 2016. J Hepatol. 2017;66:153-194.

17. Taherkhani R, Farshadpour F. Global elimination of hepatitis C virus infection: Progresses and the remaining challenges. World $\mathrm{J}$ Hepatol. 2017;9:1239-1252.

18. Kuscu F, Kömür $S$, Inal $A S$, Ulu $A C$, Kurtaran $B$, Taşova $Y$, Ünlü $B$, Mıdıklı D, Tomul ZD, Yılmaz G, Suntur BM, Aksu HSZ. Changing epidemiology of chronic hepatitis $\mathrm{C}$ in Adana. Viral Hepatitis Journal. 2014;20:15-18.

19. Üçbilek E, Abayı B, Koyuncu MB, Mıdıklı D, Gözüküçük $S$, Akdağ A, Özdoğan O, Altıntaş E, Sezgin O. Distribution of hepatitis C virus genotypes among intravenous drug users in the Çukurova region of Turkey. Turk J Med Sci. 2016;46:66-71.

20. World Health Organization. Global health sector strategy on viral hepatitis 2016-2021. Towards ending viral hepatitis. 2016. Available from: http://www.who.int/hepatitis/strategy2016-2021/ ghss-hep/en/

21. Ruta S, Cernescu C. Injecting drug use: A vector for the introduction of new hepatitis C virus genotypes. World J Gastroenterol. 2015;21:10811-10823. 